\title{
Semantic Analysis of the Wa Tautology in Subordinate Clauses with Low Independence Degree
}

\author{
Liu Yu \\ School of International Studies, Jingdezhen Ceramic \\ Institute \\ Jingdezhen, China \\ e-mail: lredfish_0@163.com
}

\author{
Zhao Junhuai \\ School of Foreign Language, Tianjin University of \\ Science \& Technology \\ Tianjin, China \\ e-mail: zjh_1x2072@hotmail.com
}

\begin{abstract}
Japanese boasts a great variety of tautological expressions, some of which carry certain unusual semantic features when these tautologies are employed in clauses. This paper attempts to analyze the $八$ (pronounced wa) tautology in subordinate clauses with low independence degree, and to explore the semantic properties of this category.
\end{abstract}

Keywords-Tautological Expression; Clause; Independence Degree; Category; Idiomatic Expression

\section{THE TYPES OF WA TAUTOLOGY}

Particle classification is adopted to classify Japanese tautology, that is, taking the particle in the tautology as the classification standard. And the Wa tautology can be roughly divided into four subclasses, which can be expressed as following:
(1) $\sim \mathrm{X}_{1}$ は $\mathrm{X}_{2}(\text { だ })^{1}$
(2) $\mathrm{X}_{1}$ は $\mathrm{X}_{2}\left(\right.$ で)、 $\mathrm{Y}_{1}$ は $\mathrm{Y}_{2}($ だ
(3) $\mathrm{X}_{1}$ は $\mathrm{X}_{2}$ でも〜
(4) $X_{1}$ は $X_{2}$ で〜

The tautology of type (1) and type (2) are in the main clause, and the tautology of (3)is in the subordinate clauses with low independence degree, and the tautology of type (4) is in the subordinate clauses with the lowest independence degree.

In Chinese and English, type (1) and type (2) are the same. Many of the earlier studies have already discussed their meaning and nature, this paper will not repeat them. This paper focuses on the discussion of type (3) in the tautology in the subordinate clauses with low independence degree.

The most obvious feature of (3) is that it will not form tautology after being translated into Chinese and English. For example:

（1）負けは負けでもやはり横綱だけあって堂々たる戦 いぶりだ。(『助詞・助動詞の辞典』)

\footnotetext{
${ }^{1} \mathrm{X} 1$ and $\mathrm{X} 2$ refer to the same noun. And the number on the right corner, the number on the right bottom corner refers to the sequence of this noun in the sentence. Under the unnecessary conditions, $\mathrm{X}$ is used to refer to the nouns forming the tautology.
}

If this sentence is translated into Chinese and English with tautology, even it's not a totally wrong sentence, but also an unnatural sentence with low recognition degree. For example, the following 2 translated sentences (the question marks before the sentence means the sentence is unnatural):

(1a)?? 就算 (即使) 输了是输了, 也不愧是横纲, 比 赛姿态堂堂正正。

(1b)?? Although a loss is a loss, it was still a true Yokozuna's fight.

To make the translation more natural, tautology is difficult to use. Please check the translation below:

(1c)不愧是横纲, 就算输了也输得堂堂正正。2

(1d)It was a true Yokozduna's fight though lost.

\section{PRIOR STUDY OF TYPE (3)}

Wherever Times is specified, Times Roman or Times New Roman may be used. If neither is available on your word processor, please use the font closest in appearance to Times. Avoid using bit-mapped fonts if possible. True-Type 1 or Open Type fonts are preferred. Please embed symbol fonts, as well, for math, etc.

In regards of the tautology of Wa, its prior study is relatively less. The author has found two theses, including Moriyama(1989) and Sakai(2007). Both of them gave the following examples:

(2) ペンギンは、鳥は鳥でも、飛べない。

(3) 鳥は鳥でも飛べない鳥は?—ペンギン。

(4) 静男は、いい奴はいい奴なんだが、変な癖がある。

But, in this paper, (4) is considered to be different with (2)(3). From the essential meaning feature, (4) is similar with the type (1) of the classification made by Liu $\mathrm{Yu}(2012)$,

\footnotetext{
${ }^{2}$ Some Japanese scholar thought that the example sentence (1) can be translated into Chinese tautology, for example: “输归 输, 但毕竟是横纲, 比赛中的表现还是很精彩的”. But, the Chinese tautology of “ $X$ 归 $X$ ” is more close to the clause of “が” “けど” in Japanese from the perspective of meaning and the independence degree of clauses. And it has obvious difference with the concessive clauses of “ても” “でも” type. Thus, the translation is not accurate.
} 
which will be clear after type (3) is analyzed in this paper later.

However, when Moriyama (2007) analyzed and discussed type(3), he made such discussion about its logic structure:

「NPでも $\mathrm{X}$ は X だ」の「Xは Xだ」は他の一項述 語と等位接続することができる。....したがって「NP でもXはXだ」の「XはXだ」は一項述語として機能 していると考えられる。

From the discussion, it can be seen that, Moriyama (2007) didn't distinguish type(3) and type (1), or analyze and explain the meaning feature of this type further, either.

Moriyama (1988) made such discussion for type(3):

属性・帰属を表す述語部分の意味を問題にする場 合、その意味が典型的に同定できるものではなく同定 可能な範囲ではあっても境界線上のものという意味を 表すものがある。

Simply speaking, it means that $\mathrm{X}$ is not a typical representation within a range, but a marginal member. This discussion reveals the basic meaning of type (3) to some extent. But the concept of "type" is not enough to express the meaning feature of this kind of sentence pattern, which can be understood from the analysis below.

\section{THE AFFILIATE DEGREE OF (3) SUBORDINATE CLAUSE}

From the sentence structure, the tautology of type (3) appears in the subordinate clause. From the sentence (4), its tautology is also in the subordinate clause from the view of structure, which may be the reason that Moriyama (2007) regarded it as the same type of 1 . There is a very important concept in Japanese subordinate clause, that is the independence degree (or affiliate degree). The concept of affiliate degree was proposed by Minami(1974) firstly, and improved by others. From the view of independence degree, Japanese subordinate clauses can be divided into several classifications. The classification of Noda(1996) is adopted in this paper. According to the discussion of Noda(1996), the Japanese subordinate clauses can be divided into the following classifications:

従属句(独立度が一番低い)「〜ながら」「〜まま」 (付带状況句)、「〜て」(継起句)など；

強い従属節(独立度が低い)「〜と」「〜たら」「〜 ば」「〜ても」時間節、連体修飾節など;

弱い従属節(独立度が高い)「〜から」「〜のに」

「〜し」「〜けれど」「〜が」など; ど。

引用節(独立度が一番高い)「〜と」「〜って」な

From the classification above, the tautology of type (3) belongs to the subordinate clause with relative low independence degree. But the sentence (4) is the subordinate clause with high independence degree. For the later subordinate clauses with high independence degree, sometimes, they cannot be called subordinate clause, namely "the difference between the main clause and subordinate clause is not clear". This compound sentence is not so much the relationship of main clause and subordinate clause as a sentence composed of two clauses with the same status, and they can be changed into two independent sentences connected by the njunctions, such as“だけど”“゙だが”“なの に" without any change of the meaning of the whole sentence. Thus, sentence (4) cannot be considered as type (3) but as type (1), and its meaning feature can be found to conform to type(1) after analyzing the meaning feature of(3).

\section{MEANing FeAture OF TYPE (3)}

Firstly, $\mathrm{X}$ of the tautology of type (3) has a feature that the meaning almost has no change after deleting the later sentence for X1, but for X2, the later sentence cannot be deleted unless the sentence will be wrong and becomes meaningless. For example:

(5)「洪さんは病気? 」

「病気は病気でも恋わずらい」(丸谷才一 400)

(6) (エグザイルはみんなヤンキーに見えるから)

「エグザイルが優勝したよ」

「A K B 48 は結局ヤンキーに勝てないか」

「ヤンキーはヤンキーでもボーカルはちゃんと歌

を歌えるんだから」

(7)晴れは晴れでも雨が降る。

If $\mathrm{X} 1$ is deleted from the following 3 sentences, they will become:

(5a)「洪さんは病気？」

「病気でも恋わずらい」(丸谷才一 400)

(6a) (エグザイルはみんなヤンキーに見えるから)

「エグザイルが優勝したよ」

「A K B 48 は結局ヤンキーに勝てないか」

「ヤンキーでもボーカルはちゃんと歌を歌えるん だから」

(7a)晴れでも雨が降る。

It can be seen that the meaning of (5a)(6a)(7a) is almost the same with(5)(6)(7).But if X2 is deleted, the situation will change completely.

(5b)「洪さんは病気？」

?「病気は恋わずらい」(丸谷才一 400)

(6b) (エグザイルはみんなヤンキーに見えるから)

「エグザイルが優勝したよ」

$\lceil\mathrm{A} \mathrm{K} \mathrm{B} 48$ は結局ヤンキーに勝てないか」

*「ヤンキーはボーカルはちゃんと歌を歌えるんだ から」

(7b)*晴れは雨が降る。

It can be seen that although (5b) isn't a wrong sentence, it makes no sense in the dialogue above. And (6b) and (7b) become wrong sentences. The feature resulted from deleting 
$\mathrm{X}$ also exists in sentence (4), which is reason that it's easy to be confused with type(3).

But, even though sentence (4) is similar with type (3) from certain extent, it still belongs to the range of type(1). Because the subordinate independence degree of its tautology is relatively high, the subordinate clause with relatively high independence degree in Japanese can be modified into an independent sentence by adding “だ”“な” and so on before the njunctions without changing the meaning of the whole sentence. Thus, the tautology of sentence (4) can be approximatively considered as in the main clause. Secondly, from the view of meaning feature, it conforms to Liu's (2012) summary of meaning feature for type (1), "for type (1), the existing difference is denied, namely no matter how marginal $X$ is, it still belongs to the range of X type of matters." The core meaning of sentence (4) focuses on that whatever odd habit or hobby Shizuo has, it still belongs to the category of “ いい奴”. The point is that the primary attribute of Shizuo is emphasized. Of course, from the view of "marginal member", type(3) has common ground with type (1). But they still have obvious difference. For example, from sentence (5), the person with surname of Hong is not sick, but has "lovesickness", which only presents some similar symptoms with real sickness on body and behaviors, but its essential is not sickness. From sentence (6), the singer“エグザイル”in this band just dresses up like a rogue, but he is not a rogue essentially. He won "AKB48"for his good singing ability. In sentence (8), it describes an infrequent weather phenomena "sunny rain", which is short. After such phenomena, it will clear up or continue raining, which cannot be predicted. So it's difficult to say if it will clear up or rain before this phenomenon disappears. So although sentence (7) is a little different with the example mentioned above, they have a common point, which is just the essential meaning feature of type(3). To a certain extent, the meaning feature of type (3) is exactly opposite with the meaning feature of type (1). Type (1) is to present some representation or features of the marginal members of $\mathrm{X}$, and then emphasize "despite $\mathrm{X}$ is a marginal member, but essentially it still belongs to this category" with the tautology of X. But type (3) presents a category by putting $\mathrm{X}$ in a subordinate clause, then in the main clause, $\mathrm{X}$ is considered having separated from this category subjectively. In summary: type (1) is "essential existing without the form", but type (3) is "form existing without the essential". But what should be noticed is that a core factor of tautology is proposed in stating the meaning features of type (1) and type (2), that is, $X$ has an invariant factor, so type (3) also has such a same key factor, which means that even thought the meaning feature of type (3) regards X has been separate from its original category subjectively, but its form, namely its representation is still left remaining unchanged.

If taking the meaning feature of type (3) as the standard, sentence $(5) \sim(7)$ are easy to explain and unify. Regarding sentence (7), it can be understood as: "sunny rain" cannot be explained as fine day or rainy day, but at least it's separated with the category of fine day. Therefore, for sentence (5)(6), they can be explained as: even though lovesickness has the word "sickness", essentially it's not a sickness, it's been separated with the category of sickness. “エグザイル” is Japanese. Even though its appearance is very alike with American, essentially it has been separated with the category of American. For the meaning feature of type (3) with "form existing without essential”, the example sentence of “なぞな ぞ” (a fixed form of guessing game in Japanese) is an enough proof. For example:

(8)パンはパンでも、食べられないパンは?

The answer of this riddle is “パンダ” (パンだ)" that taking use of partial tone. The pronunciation of panda in Japanese is the same with "is bread(パンだ)", but essentially it doesn't belong to the category of "bread" or "food".

Certainly, language is the product of the consciousness of human beings essentially, but exception exists. The sentence (9) is a good example:

(9) (浅谷は女刑事。武内と平野は浅谷の同僚。)

武内「そこでさあ、頼みにくいんだけど、ちょつ と協力を一一—」

浅谷「協力? 八——ーン、わたしの女友だちを紹 介しろってんでしょう」

平野「え?」

浅谷「残念ながら無理よ。わたしの友人はみ〜〜 な結婚してますから!」

武内「ほ〜〜〜みんな…..浅谷だけ行き遅れたわ け? 」

浅谷「わたしはね〜！仕事一筋に生きるため に...」

武内「わかった、悪かった!こっちの話をちゃん ときいてくれ! ! 実は......きみにキス跡をつけてほ しいのだ！！」

浅谷「え...! ? 」

平野「恋人をつれていくのは無理だから顔にキス マークつけてくんスょ」

武内「そうすりゃあ恋人につけられたっていえる だろ。たのむ! 浅谷。」

平野「頼める女は浅谷さんしかいないんスょ！」

（その直後、 2 人とも浅谷にビンタを張られた）

跡は跡でもビンタの跡 $\ldots . . . .$.

平野「だいたい浅谷に頼もうっていうのがまちが いなんスょ！！」

武内「なにをいうか！！てめえ〜が『浅谷でがま んするから』なんていうから、ブッたたかれるん だ!！」(『キャッツ・アイ』8 2273$)$

In this example, it seems that the trace of slap on face cannot be said it's not trace. It still belongs to trace essentially. It's should be noted that type (3) is just a common example with two categories. Suppose the category in subordinate clause is $\mathrm{A}, \mathrm{X}$ in the main clause represents the real category of essence of things, thus the meaning 
feature of type (3) can be summarized as "form in A and essence in B". However, from the example of (9), it has three categories literally: “マーク”、“ビンタのマーク”,“キス マーク”.・ビンタのマーク” and “キスマーク”. Although they are two completely different categories, they are all included in the bigger category of “マーク”. The previous two common examples only have two categories, which are not inclusion relation. Trace of slap on face cannot belong to the category of "hickey", but it belongs to the bigger category of "trace". The inclusion example makes the example special. It's seems it's an exception, but it may be an error.

As this example is not only a simple sentence but has inseparable relations in the context, making it have the meaning of "although the trace of slap on face is a kind of trace, but it doesn't carry the point of Takeuchi and Hirano, after all it's not hickey". Overall, for this example, the trace of slap on face doesn't belong to the category the speaker really wants. In the view of this key meaning, “キス” is the core and key, so these three categories are only mechanical literalism or separate semantics. In this example, the essence of the category of “キスマーク” should be “キス”, “マー ク" that is only the representation. Thus, there will be no such there categories but two categories. One category takes “キス” as the essence, another category takes “ビンタ” as the essence. But both of them have a same representation " $\checkmark$ 一ク". So the meaning feature of "form existing without essence" summarized in this paper is suitable. This example is special in language form. The other examples are just the literal meaning of $\mathrm{X}$, which represents the essence of a category. But this special example is just the literal meaning without representing the essence of category but the representation of category.

At last, go back to the sentence (4), through the analysis above, it can be seen that the meaning feature of (4) is not the meaning feature of type (3). From the overall meaning of the sentence, although the speaker wants to express the oddity Shizuo has is not good, but doesn't deny Shizuo, it doesn't separate from the category of"いい奴”. Since it doesn't has the meaning of separating the category, it doesn't belong to type (3). Although sentence (4) doesn't highlight, its overall meaning still conform to the feature of "existing essence without form", therefore, although it has different language form, it still belongs to type (1).

\section{CONCLUSION}

This paper analyzes the tautology in subordinate clauses with low independence degree (type (3)), and summarizes the meaning features. Several key points can be summarized as follows:

1) The tautology appears in the subordinate clauses with low independence degree;

2) After translated into Chinese and English, the tautology will not appear anymore;

3) Contrary to the meaning of type (1), the whole meaning of the sentence is: subjectively regarding that $\mathrm{X}$ has been divorced from the original category, but its original representation is still retained;

4) The literal meaning of $X$ is sometimes the essence of the original category, sometimes is the representation of its original category.

For the analysis of the meaning feature of type (4), there are tautology sentences in the category of $カ$ カ and $モ$, which will be discusses in the future theses.

\section{REFERENCES}

[1] Tomohiro Sakai. 日本語における文的トートロジーと述語的トー トロジー[J].Language and Culture

Department - Meisei University Japanese Culture Research College,2007, (15) : 152-162

[2]野田尚史.「は」と「が」[M].くろしお出版,1996

[3] 南不二男.現代日本語の構造[M].大修館 Bookstore, 1974

[4] 森山卓郎. 自同表現をめぐって[J]. 待兼山論叢日本語 編,1989,(23):1-13

[5] 劉爆.現代日本語トートロジー表現の研究[D].名古屋大学国際言 語文化研究科修士論文, 2012 